\title{
Retraction Note: Environmental cost control of coal industry based on cloud computing and machine learning
}

\author{
Yanni Luo ${ }^{1}$
}

Published online: 25 November 2021

C) Saudi Society for Geosciences 2021

Retraction Note: Arabian Journal of Geosciences (2021) 14: 1081 https://doi.org/10.1007/s12517-021-07411-w

The Editor-in-Chief and the Publisher have retracted this article because the content of this article is nonsensical. The peer review process was not carried out in accordance with the Publisher's peer review policy. The author has not responded to correspondence regarding this retraction.

The original article can be found online at https://doi.org/10.1007/ s12517-021-07411-w.

Yanni Luo

luoyanni1234@163.com

1 School of Accounting, Xi' an Eurasia University, Xi' an 710065, Shaanxi, China 